Кубишина Н.С.

канд. економ. наук, доцент

Ковальчук Т.В.

Національний технічний університет Украӥни «КПI»

\title{
ГЕНЕРУВАННЯ ІДЕЙ ЯК ОСНОВНИЙ ЕТАП РОЗРОБЛЕННЯ НОВОГО ТОВАРУ НА ПРОМИСЛОВОМУ ПІДПРИЕМСТВІ
}

\author{
ГЕНЕРИРОВАНИЯ ИДЕЙ КАК ОСНОВНОЙ ЭТАП РАЗРАБОТКИ НОВОГО \\ ТОВАРА НА ПРОМЫШЛЕННОМ ПРЕДПРИЯТИИ
}

\section{THE GENERATIONOF IDEAS OF THE MEAIN STAGE OF DEVELOMENT OF A NEW RODUCT IN INDUSTRIAL ENTERRISE}

В статті розглянуто прочес генерування ідей як один з найскладніших етапів розроблення нового товару з урахуванням аналізу внутрішніх та зовнішніх факторів маркетингового середовища, щзо виливають на діяльність промислового підприємства.Уточнено способи організачії розроблення нового товару на підприємстві. Проаналізовано важливість правильного планування та реалізаиіі першого етапу розроблення нового товару.Запропоновано узагальнену схему взаємозв'язків між відділом розроблення нового товару на підприємстві та іншими основними відділами. Детально розглянуто зовнішні та внутрішні джерела ідей , які мають бути враховані окремо кожним відділом компанії. Визначено детальний перелік джерел ідей нового товару для співробітників відділу маркетингу.Відокремлено основні способи, які можуть бути використані при мотивації керівництвом співробітників для пошуку та фіксування ідей нового товару. Визначено основні методи генерування ідей, які рекомендовано використовувати на промисловому підприємстві з метою отримання максимальної кількості ідей для знаходження найціннішої серед них на наступних етапах розроблення нового товару.

Ключові слова: ідея, процес пошуку ідей, новий товар, джерела ідей, методи генерування ідей.

В статье рассмотрен процесс генерирования идей как один из самых сложных этапов разработки нового товара на основе анализа внутренних и внешних факторов маркетинговой среды, влияющие на деятельность промышленного предприятия. Уточнено способы организации разработки нового товара на предприятии. Проанализированы важность правильного планирования и реализации первого этапа разработки нового товара. Предложено обобщенную схему взаимосвязей между отделом разработки нового товара на предприятии и другими основными отделами. Детально рассмотрены внешние и внутренние источники идей, которые должны быть учтены отдельно каждым отделом компании. Определены подробный перечень источников идей нового товара для сотрудников отдела маркетинга. Обособленно основные способы, которые могут быть использованы при мотивации руководством сотрудников для поиска и фиксирования идей нового товара. Определены основные методы генерирования идей, которые рекомендуется использовать на промышленном предприятии с целью получения максимального количества идей для нахождения ценной среди них на следующих этапах разработки нового товара.

Ключевые слова: идея, процесс поиска идей, новый товар, источники идей, методы генерирования идей. 
The article examines the process of idea generation as one of the most difficult stages of developing a new product based on the analysis of internal and external factors of marketing environment affecting the activity of industrial enterprise. Clarified ways of organization of developing a new product in the company. Analyzed the importance of proper planning and implementation of the first phase of the development of a new product. Proposed the generalized scheme of relationships between department of development new product in the company and other main departments of the company. Considered in detail internal and external sources of ideas which must considered separately by in each department. Determined detailed a list of ideas for new product for marketing department staff. Highlighted the main ways, which can be used to motivate the staff for find and fix new product ideas. Identified the main methods of generating ideas that recommend to the industrial company to obtain the maximum number of ideas for finding the most valuable among them on the next stages of new product development.

Keywords: the idea, the process of finding ideas, new product, sources of ideas, methods of generating ideas.

Вступ. Сучасна економіка України характеризується високим рівнем динамічності та нестабільності. Звичайно, це негативно впливає на діяльність суб'єктів господарювання, адже вони не завжди в змозі швидко адаптуватися до змін зовнішнього середовища. На даний момент одним 3 найбільш дієвих засобів для приведення у відповідність внутрішніх можливостей розвитку підприємств умовам ринку є створення та поширення інновацій.

У зв’яку з високою важливістю інноваційної діяльності для підприємств, процеси розроблення нових товарів висвітлювали у своїх працях багато вітчизняних авторів, серед яких В. Кардаш, В. Кучеренко, І. Заблодська, Н. Кубишина, Н. Чернік, С.Ілляшенко та інші. Серед зарубіжних авторів, які внесли великий вклад у вивчення даного питання можна назвати Б. Бермана, Г. Армстронга, Ж-Ж. Ламбена, І. Бланка, Е. Дихтля, К. Ланкастера, Т. Левітта, Р. Райта, Ф. Котлера та інших. Проте, в науково-практичній літературі питання детального розгляду процесу пошуку ідей нового товару на промисловому підприємстві висвітлено в недостатній мірі.

Постановка завдання. Метою статті євизначення сутності процесу генерування ідей на підприємстві, виявлення основних способів організації даного процесу, джерел надходження ідей до кожного відділу, мотивації співробітників 3 метою їх залучення до даного процесу та методів, які допомагають отримати максимальну кількість ідей.

Методологія. Теоретичну i методологічну основу дослідження складає системний підхід до динамічного аналізу економічних процесів, сучасні теоретичні, практичні та наукові методи пізнання: порівняльний аналіз і метод логічного узагальнення, що найбільше відповідають тематиці проведеного дослідження. Інформаційною основою виступають наукові праці вітчизняних i зарубіжних вчених, матеріали періодичних видань, Інтернет-ресурси.

Результати дослідження. Для того, щоб підприємство підвищувало свою конкурентоспроможність i мало можливість зайняти лідерські позиції, необхідно дотримуватися двох напрямів діяльності - розробляти i впроваджувати інновації та реалізовувати заходи комплексу маркетингу, які спрямовані на комерціалізацію інновацій. 
Найбільш змістовним є поняття інновації, запропоноване в [7]: інновація це кінцевий результат нововведення, спрямований на досягнення відповідного ефекту і створення нових або вдосконалених конкурентоспроможних товарів, які задовольняють потреби споживачів, він може охоплювати всі сфери діяльності підприємства та сприяє розвитку і підвищенню його ефективності.

Таким чином, для ведення інноваційної діяльності необхідно розробляти та спроваджувати на ринок нові товари. Під «новим товаром» розуміють новий продукт, що надійшов на ринок і відрізняється від існуючих товарів схожого призначення якою-небудь зміною споживчих властивостей [4].

Прийняття рішення про розроблення нових товарів промисловим підприємством залежить в основному від інноваційної культури, ролі вищого менеджменту, комунікаційних і технологічних тенденцій, залучення середнього менеджменту в оцінний процес, систематичного вивчення потреби в інноваціях і технологіях і ув'язки рішень 3 процесом розподілу ресурсів.

За останні роки в Україні спостерігається зростання кількості промислових підприємств, які впроваджують інноваційні товари на ринок, що видно з рис. 1 . В основному це пов'яано з тим, що саме завдяки інноваціям компанії мають можливість підвищити свою конкурентоспроможність. Однак, кількість реалізованих нових товарів протягом останніх років спадає. Це пояснюється впливом факторів маркетингового середовища та помилками в розробленні стратегії нового товару промисловими підприємствами.

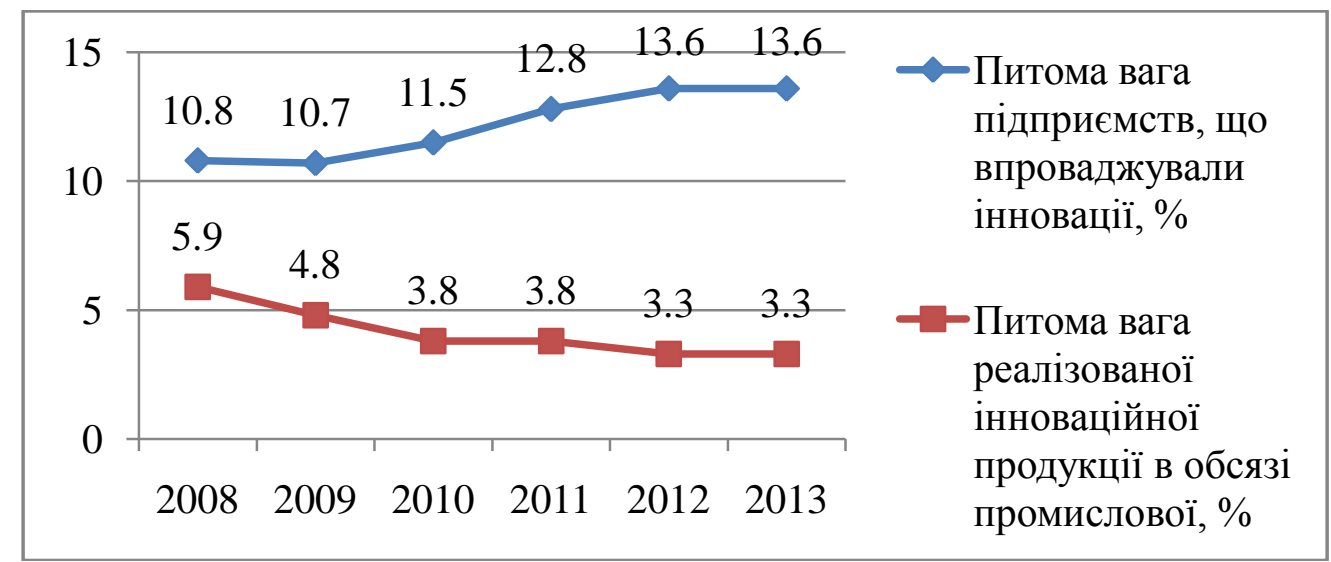

Рис. 1. Впровадження інновацій на промислових підприємствах України[2]

Після того, як підприємство прийняло рішення про виведення нового товару на ринок, перед ним постає завдання ретельного спланувати та організувати даний процес, який складається з наступних етапів:1) генерування ідей; 2) відбір ідей; 3) розробка і тестування концепції товару; 4) розробка стратегії маркетингу; 5) проведення економічного аналізу; 6)створення прототипів; 7) пробний маркетинг; 8) комерціоналізація [1].

Організація розроблення нового товару може здійснюватися по-різному:

- продуктовому керуючому паралельно 3 його роботою 3 поточними продуктами доручається також розроблення нового продукту;

- створюються спеціальні тимчасові робочі групи; 
- створюються спеціальні відділи по розробленні нових продуктів, які займаються всім процесом: від генерації ідей до їх матеріалізації.

На промислових підприємствах рекомендується використовувати останній варіант, а саме створити окремий відділ, до складу якогонеобхідно включити представників кожного відділу. Такий підхід пояснюється тим, що процес створення нового товару має інтегрований характер i включає в себе як фінансові, маркетингові, виробничі, збутові так і інші аспекти. Таким чином, керівництву підприємства необхідно детально спланувати склад даного відділу, сформувати основні цілі та послідовність дій.

Принципова перевага такої організації полягає в тому, що відповідальність за розроблення нового продукту покладається на керівника високого рівня, що підкоряється президентові компанії. Тому:

- забезпечується безпосередня участь вищого керівництва в роботах зі створення нових продуктів;

- рішення, пов'язані 3 розробкою нових продуктів, узгоджуються i приймаються в мінімальні терміни.

Першим етапом 3 якого розпочинає роботу відділ розроблення нового товару є генерування ideй. Це зазвичай найскладніша частина проекту, яка полягає в створенні найрізноманітніших ідей. На наступних етапах кількість даних ідей зменшується з метою вибору найбільш цінної.

Ідея товару - це загальне уявлення про можливий продукт, який підприємство могло б запропонувати споживачеві. Генерування iдей - процес виникнення (появи, створення), постійного і систематичного пошуку, накопичення, відбору та формування портфеля ідей нового продукту [8].

Даний етап є найбільш складним, оскільки потребує правильної організації процесу збору ідей, залучення до їх пошуку всіх співробітників підприємства. Це є надзвичайно важливим, оскільки саме ідея нового товару може визначати весь подальший розвиток бізнесу. Таким чином, ідея $є$ дуже важливою в діяльності інноваційного промислового підприємства, а отже необхідно придавати велику значущість ії успішному пошуку.

На сьогоднівеликий інтерес привертає проблема формування ідей нових товарів на українських промислових підприємствах, де значна кількість високоякісних ідей ніколи не пропонується для оцінки та розгляду. Так відбувається тому, що керівництво оцінює просування поточних проектів вище, ніж генерування ідей для нових товарів. Ідеї, які, швидше за все, не пройдуть перевірку на затребуваність і своєчасність, ніколи не розглядатимуться.

Така ситуація також пояснюється і тим, що існує велика кількість джерел ідей нового товару, надходження яких важко структурувати. В даному випадку можна розглянути результати опитування 157 успішно діючих японських компаній.Мета опитування полягала у виявленні основних джерел плідних ідей нових продуктів, що показано в таблиці 1, де цифри показують число компаній у \%, які вказали відповідне джерело ідей нового продукту в якості основного, тому загальна сума перевищує 100\%.3 наведених даних видно, що більша 
частина ідей нових товарівнадаєтьсявідділом збуту, службою організаційного розвиткута виробничо-технічним відділом.

Таблиця 1

Джерела появи ідей інновацій в 157 успішних японських компаніях [9]

\begin{tabular}{|l|l|}
\hline \multicolumn{1}{|c|}{ Джерело ідей } & \multicolumn{1}{c|}{ Число компаній у \% } \\
\hline Відділ збуту & 73 \\
\hline Служба організаційного розвитку & 70 \\
\hline Виробничо-технічний відділ & 58 \\
\hline Споживачі & 55 \\
\hline Вище керівництво & 53 \\
\hline Дослідна лабораторія & 44 \\
\hline Відділ планування & 29 \\
\hline Збутова мережа & 28 \\
\hline Торгові агенти & 15 \\
\hline Інші джерела & 11 \\
\hline Університети & 6 \\
\hline Інші дослідницькі організації & 6 \\
\hline Рядові працівники & 4 \\
\hline Співробітники іноземних організацій & 2 \\
\hline
\end{tabular}

Важкість формалізації формування інноваційних ідей пояснюється і тим, що генерування ідей є творчим процесом, який вимагає від учасників прояву творчих здібностей та якостей. Таким чином, авторами пропонується виділити підхід до організації забезпечення процесу генерування ідей на промисловому підприємстві, що представлений на рис. 2.

Зовнішні джерела ідей Внутрішні джерела ідей

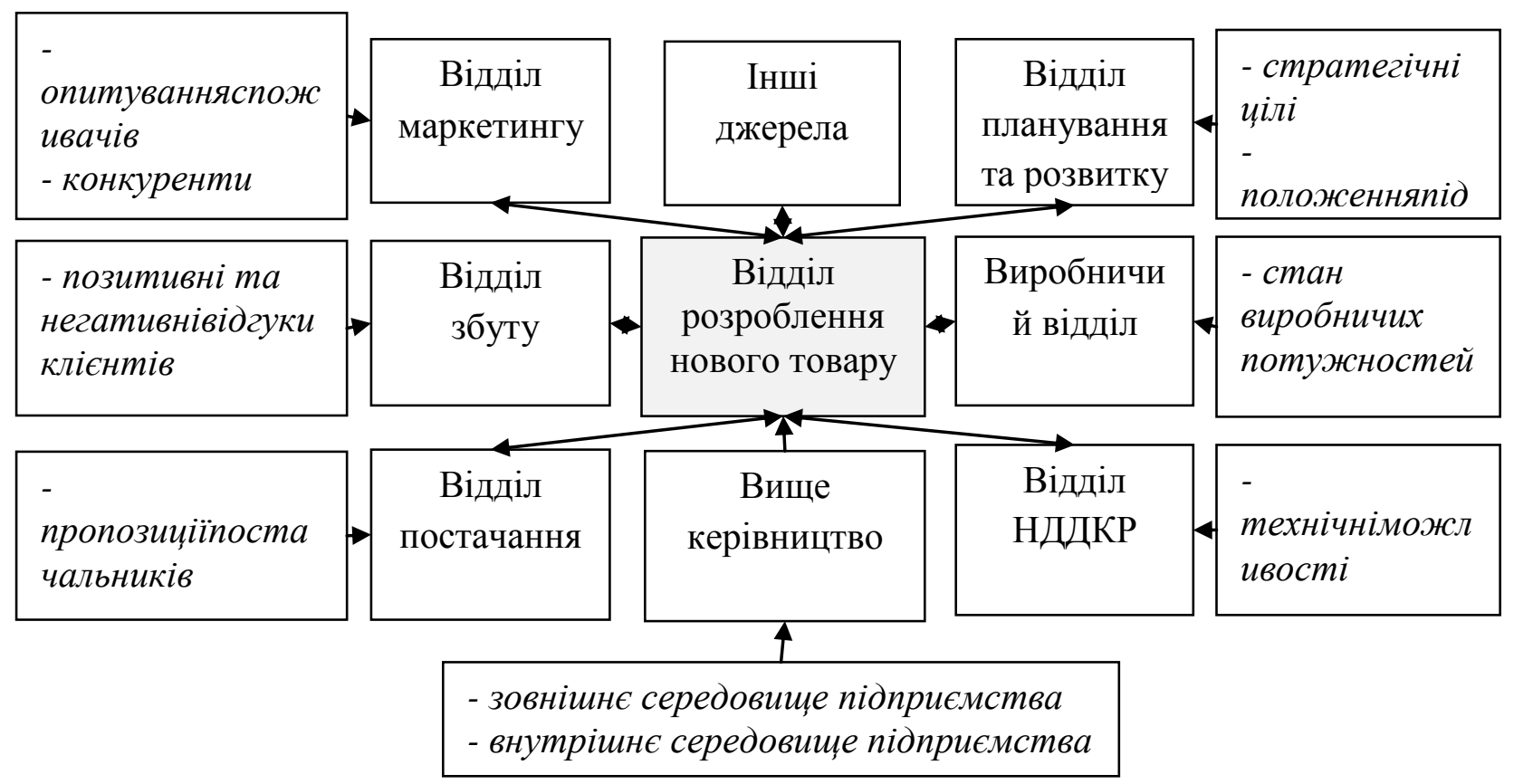

Рис. 2. Схема взаємозв'язків між відділом розроблення нового товару та іншими відділами підприємства [джерело: власна розробка авторів]

Загалом, найбільш оптимальним варіантом при розробленні нового товару на підприємстві є створення спеціального відділу, який буде реалізовувати всі 
етапи даного процесу. На роботу відділу потрібно керівництву необхідно спрямувати максимальні ресурси та зусилля, залучити кращих співробітників 3 усіх відділів організації з метою успішного виведення товару на ринок.

Процес генерування ідей розпочинається з їх пошуку та фіксування. Всі джерела від яких надходять ідеї до даного відділу можна поділити на дві групи:

- зовнішні, до яких можна віднести в цілому суб'єкти, з якими взаємодіє підприємство, або які впливають на його діяльність. На промисловому підприємстві серед відділів, які працюють із зовнішніми джерелами та звідки черпають ідеї нового товару можна в основному можна виділити відділи маркетингу, збуту та постачання.

- внутрішні, до яких відносять процеси в організації, а саме результати діяльності відділів, на основі яких співробітники формують ідеї нового товару. В даному випадку пропонується до цієї групи віднести в основному відділ стратегічного планування та розвитку, виробничий відділ та відділ НДДКР. Це найважливіші підрозділи, які відмінно знають переваги та недоліки роботи компанії, iï фінансові, технічні та виробничі можливості, оцінюють сучасний стан та перспективи розвитку.

Відповідно до цього, всі ідеї від внутрішніх та зовнішніх джерел необхідно фіксувати кожним відділом в залежності від його спеціалізації та передавати на розгляд до відділу розроблення нового товару. В кожному відділі необхідно призначити людину в обов'язки якої буде входити збір та фіксування ідей. В результаті такого підходу кожен відділ буде зацікавлений в пошуку ідей, що дозволить зібрати максимальну їх кількість та не упустити найпривабливішої. Розглянемо джерела ідей, які варто враховувати відділам підприємства.

Відділ стратегічного планування та розвитку. Основна роль відділу полягає у виробленні рекомендацій на основі поточної і прогнозованої ситуації, та видачі рекомендацій щодо подальших дій на довгостроковий період. Працівники даного відділу на основі аналізу та приходу до певних висновків про роботу підприємства i досягнення ним поставлених цілей, можуть запропонувати ідеї нового товару, виведення якого на ринок покращить положення компанії.

Виробничий відділ.Даний відділ займається безпосередньо виробництвом всього асортименту продукції. Таким чином, працівники відділу можуть висувати ідеї на основі аналізу ритмічності роботи, підвищення якості продукції, впровадження нової техніки і технологій, комплексної механізації та автоматизації виробництва, роботи обладнання, витрачання матеріальних ресурсів, тривалостітехнологічного циклу, комплектності випуску продукції, загального технічного та організаційного рівня виробництва.

Biddiл НДДКР. Ідеї нового товару у працівників даного відділу можуть виникнути при проведенні фундаментальних та прикладних досліджень в рамках науково-дослідної роботи. Даний відділ володіє повною детальною інформацію про товари компанії, знаючи переваги та недоліки у проектуванні та конструкторській розробці. Таким чином, ідеї запропоновані даним відділом 
надзвичайно важливі, оскільки засновані на конструкторській та технічній документації та на виробничих можливостях підприємствах.

Вище керівництво. Керівники вищої ланки відповідають за прийняття стратегічно найважливіших рішень для промислового підприємства в цілому. Вони володіють повною інформацією про положення компанії на ринку, про основні загрози, фактори, які впливають на іiі успішність. Таким чином, вище керівництво може формувати ідеї нових товарів під впливом як ситуації всередині компанії так і зовнішньої обстановки.

Biddiл постачання.Працівники даного відділу закуповують всі необхідні матеріали для виробництва у постачальників. Останні в свою чергу можуть стати джерелом ідей нового товару, шляхом пропозиції нових деталей та матеріалів, надання інформації про закупки конкурентів компанії, рекомендацій про спеціальні вироби, які можуть покращити якість продукції підприємства на основі пропозиції вигідних умов співробітництва, оскільки вони завжди зацікавлені в економічному успіху компаніі.

Biddiл збуmy.Даний відділ може запропонувати надзвичайно важливі ідеї нового товару, оскільки співробітники напряму взаємодіють із основним зовнішнім джерелом, а саме клієнтами промислового підприємства. Відділ володіє інформацією про позитивні та негативні сторони виробленої продукції на основі відгуків та пропозицій клієнтів, які в свою чергу надають всю необхідну інформацію про результати використання виробів.

Відділ маркетингу.Вклад даного відділу у відділ розроблення нового товару є найзначнішим. В першу чергу тому, що працівники аналізують велику кількість зовнішніх джерел, які впливають на діяльність компанії та знають положення не тільки підприємства на ринку, а ї його основних конкурентів. В основному зовнішніми джерелами ідей нового товару для співробітників даного відділу можуть бути наступні:

- Опитування споживачів про шляхи вдосконалення існуючих продуктів i про нові продукти, які вони хотіли б придбати. При опитуванні акцент робиться на негативних аспектах, так як саме вони можуть стати джерелом ідей нового або удосконаленого продукту.

- Прогнози розвитку національної економіки та тенденції розвитку ринку. Аналіз цих прогнозів дозволяє визначити потенційні можливості для того чи іншого продукту в мінливому середовищі.

- Статті та рубрики, присвячені новим продуктам в спеціалізованих та економічних журналах.

- Матеріали з галузевих семінарів, конференцій, симпозіумів і т.д.

- Публікації, присвячені діяльності основних конкурентів.

- Інформація про нові патенти.

Інші джерела.Також джерелами ідей нового товару можуть виступати: співробітники інших відділів підприємства; дослідницькі організації; університети, що співпрацюють 3 компанією; спеціалізовані організації, що займаються науковими дослідженнями і розробками; представники торговопосередницьких організацій та інші. 
Пошук нових ідей нового товару потребує залучення всіх співробітників організації до даного процесу. Тому, для того, щоб кожен працівник був зацікавлений в генеруванні ідей необхідно стимулювати персонал. Для цього потрібно вищому керівництву створити спеціальні програми по стимулюванню та поінформувати про них кожен відділ, який в свою чергу розповсюдить інформацію серед працівників. В рамках даних програм кожен працівник оповіщається про те, що його ідея буде гарантовано розглянута та оцінена. Зазначені програми передбачають виплату премій та інші винагороди за найбільш цінні ідеї. Імена переможців таких конкурсів публікуються у друкованому виданні компанії. Таким чином, кожен співробітник організації буде мотивований брати учать в процесі генерування ідей нового товару, що допоможе отримати велику кількість різних ідей, що і є основною метою даного етапу.

Також можна мотивувати окремо відділи підприємства, організувавши конкурс в рамках якого переможцем буде визначений той відділ, який зібрав максимальну кількість ідей. Результати конкурсу буде також опубліковано в друкованому виданні організації. Таким чином, кожен відділ може використовувати різні методи генерування ідей. Авторами узагальнено дані методи та наведено ті, якірекомендовано до використання на промисловому підприємстві (таблиця 2).

Таблиця 2

Методи генерування ідей нових товарів[3, 5, 6]

\begin{tabular}{|c|c|}
\hline $\begin{array}{l}\text { «Мозковий } \\
\text { штурм» }\end{array}$ & $\begin{array}{l}\text { Являє собою неструктурований процес генерування ідей, спонтанно } \\
\text { пропонованих учасниками. В основі методу лежить ідея про те, що для } \\
\text { пробудження творчої ініціативи людини треба відірвати ії із звичної } \\
\text { обстановки і помістити в незвичайні умови, наприклад, зробити } \\
\text { учасником гри або дискусії з елементами гри. }\end{array}$ \\
\hline Синектика & $\begin{aligned} \text { Процес вирішення проблеми складається з наступних основних стадій: } \\
\text { - } \\
\text { - } \\
\text { - } \\
\text { - посталіз проблеми; } \\
\text { - } \\
\text { - постаноння і пропозиції, що виникають відразу; } \\
\quad \text { збільшення дистанції між базовим і можливим новим рішенням за } \\
\text { допомогою аналогій; } \\
\text { - } \\
\text { - порив фантазії; } \\
\text { генерування можливого рішення. }\end{aligned}$ \\
\hline $\begin{array}{l}\text { Метод } \\
\text { контрольних } \\
\text { питань }\end{array}$ & $\begin{array}{l}\text { Припускає використання списку питань або пропозицій, що мають } \\
\text { відношення до аналізованої проблеми. Питання складаються у вільній } \\
\text { формі }\end{array}$ \\
\hline $\begin{array}{l}\text { Матричне } \\
\text { структурування } \\
\text { проблем }\end{array}$ & $\begin{array}{l}\text { Являє собою метод систематизації пошуку нових ідей шляхом побудови } \\
\text { матриці, стовпці якої відповідають обговорюваним варіантам продукту і } \\
\text { послуг, а рядки - ринковим атрибутам цих товарів, записаних у вигляді } \\
\text { питань. Відповіді по кожному товару записуються у клітини матриці. }\end{array}$ \\
\hline $\begin{array}{l}\text { Діаграма причин } \\
\text { і результатів }\end{array}$ & $\begin{array}{l}\text { Одним із способів побудови діаграми є спосіб на основі аналізу } \\
\text { розсіювання, який складається з наступних етапів: } \\
\text { - } \\
\text { - } \\
\text { чормуско опися група людей, що володіють необхідними знаннями; } \\
\text { необхідно знайти; }\end{array}$ \\
\hline
\end{tabular}




\begin{tabular}{|c|c|}
\hline & $\begin{array}{l}\text { - } \quad \text { на великому аркуші паперу позначається розглянута проблема у } \\
\text { вістрі великої стрілки; } \\
\text { - } \quad \text { ідентифікуються категорії (люди, процеси, зовнішні умови, } \\
\text { робоче середовище) можливих причин виникнення даної } \\
\text { проблеми і наносяться позначення близько ліній, що виходять } 3 \\
\text { основної стрілки; } \\
\text { - } \\
\text { для кожної категорії методом мозкового штурму виявляються всі } \\
\text { можливі причини, які позначаються на відповідній гілці діаграми; } \\
\text { - } \quad \text { далі причини аналізуються і виділяються найважливіші з них. }\end{array}$ \\
\hline $\begin{array}{l}\text { Діаграма } \\
\text { спорідненості }\end{array}$ & $\begin{array}{l}\text { Виявлення взаємозв'язків між окремими ідеями та рішеннями, які на } \\
\text { перший погляд не мають нічого спільного. Це досягається шляхом } \\
\text { угруповання ідей і рішень та виявлення глибинних взаємозв'язків між } \\
\text { отриманими групами. }\end{array}$ \\
\hline
\end{tabular}

Таким чином, дані методи можуть використовувати як окремі відділи так i загальний відділ розроблення нового товару. Вибір методу залежить від специфіки роботи підприємства, товарної категорії та культури всередині організації. Якщо підприємство проводить інноваційну діяльність і планує постійно розробляти та вдосконалювати товари, то необхідно, щоб ідеї з'являлися та висувалися завжди, що гарантуватиме збір максимальної кількості ідей, серед яких обов'язково буде та, яка принесе успіх підприємству.

Отже, практика показує, що більшість підприємств, які успішно розвиваються на ринку, свій успіх пояснюють саме впровадженням на ринок нових товарів. Однак процес розроблення таких товарів $\epsilon$ надзвичайно складним, оскільки потребує в основному фінансових, часових та інтелектуальних затрат. Керівництво підприємства повинне відповідально підійти до організації даного процесу, звернувши значну увагу саме на генерування ідей. Найбільш цінна ідея, яка принесе успіх підприємству може бути навіть не розглянута. Тому, правильна організація процесом їх пошуку дозволить зібрати максимальну кількість ідей та не упустити найважливішої.

Висновки. Основні положення наукової новизни отриманих результатів дослідження полягають у визначенні процесу генерування ідей як одного 3 найскладніших етапів розроблення нового товару. Рекомендовані теоретичні та практичні засади щодо організації даного процесу на промисловому підприємстві. Запропоновано схему взаємозв'язків всередині підприємства під час реалізації процесу пошуку ідей нового товару. Також слід звернути увагу, що правильна організація процесу генерування ідей сприятиме підвищенню ефективності впровадження інноваційних розробок.

\section{Література:}

1. Армстронг Г., Котлер Ф. Введение в маркетинг, 8-е издание. : Пер. с англ. - М.: ООО «И.Д. Вильямс», 2007. - 832 с.

2. Державна служба статистики України. - [Електронний ресурс]. - Режим доступу: http://www.ukrstat.gov.ua/

3. Заёнчик В.М. Основы творческо-конструкторской деятельности: предметная среда и дизайн : учебник для студ. высш. учеб.заведений / В. М. Заёчник, А. А. Карачёв, В. Е. Шмелёв. - М.: Издательский центр «Академия», 2006. - 320 с. 
4. Кардаш В.Я. Товарна інноваційна політика [Текст]: Підручник / В.Я. Кардаш, І.А. Павленко, О.К. Шафалюк. - К.: КНЕУ, 2002. - 266 с.

5. Котлер Ф.Латеральный маркетинг: технологияпоискареволюционныхидей / ФилипКотлер, Фернандо Триас де Бес; Пер. с англ. - М.:АльпинаПаблишерз, 2010. $-206 \mathrm{c}$.

6. Ламбен Жан-Жак. Стратегический маркетинг. Европейская перспектива. Пер. сфранцузского. -СПб. : Наука, 1996.- 534 с.

7. Менеджмент та маркетинг інновацій: Монографія / За заг. ред. д.е.н., проф. С.М. Ілляшенка.-Суми: ВТД «Університетська книга»,2004.- 616 с.

8. Рыкалина О.В. Взаимодействие отделов логистики и маркетинга в процессе разработки новых продуктов / Рыкалина О.В.// Маркетинг и маркетинговые исследования. - 2014. - №3 (111) - с.162-169.

9. ТоёхироКоно. Стратегия и структура японскихпредприятий. : Пер. с англ.- М.: Прогресс, 1987. -383 с. 